\title{
Chest $x$ ray screening for lung cancer at three British chromates plants from 1955 to 1989
}

\author{
C J Schilling, J M Schilling
}

\begin{abstract}
Chest $\boldsymbol{x}$ ray screening for lung cancer had been undertaken over a period of 34 years, initially at yearly intervals, then at eight-monthly intervals, on chromates workers at three plants in the United Kingdom. A review of the records of 229 employees who were diagnosed as having carcinoma of the lung during the screening programme was conducted. Survival data were available on 124 cases (123 now deceased) who constitute the study population. The cases were analysed by age and regularity of attendance for screening. The numbers detected by works $x$ ray screening and by other means were determined with five and 10 year survival rates. A modest but predictable improvement in the five year survival of those who attended regularly for radiography was shown. Taking the total population of cases for whom screening was available, no significant improvement in five year survival was found.
\end{abstract}

In the United Kingdom in the 1950 s chromates were produced in three plants (A, B, and C). Because of reports of an increased risk of carcinoma of the lung among chromates workers ${ }^{12}$ and studies at the chromates plants ${ }^{34}$ chest $x$ ray screening was introduced in 1955. This was undertaken annually at all three plants until February 1964. After this date screening was conducted at eight monthly intervals until 1989 at $C$; until closure at $A$ in 1966; and until closure at B in 1967. At all three locations screening chest radiography was available to all employees, exemployees, and pensioners.

It was considered appropriate to assess the effectiveness of this screening programme and to this end a review was undertaken of the medical records of employees at the three plants who were diagnosed as having lung cancer during the period covered by the $x$ ray screening programme (1955 to 1989 ).

A study based on the mass radiography service in

4 Albion Square, London E8 4ES

C J Schilling, J M Schilling the United Kingdom, published in $1969,{ }^{5}$ showed a modest improvement in the five year survival (15\%) of those screened six-monthly compared with a control population (five year survival $6 \%$ ).

A major study, reported in $1986,{ }^{6}$ of chest $x$ ray screening at four-monthly intervals in heavy smokers failed to show a significant improvement in mortality compared with a non-screened population; however, the five year survival was significantly improved in the screened population compared with the control group, due most probably, to earlier diagnosis.

Geddes ${ }^{7}$ investigated the exponential model of tumour growth, which describes growth rate in terms of volume doubling time. This model predicts that a single cell of $10 \mu \mathrm{m}$ diameter will become a tumour of $1 \mathrm{~mm}$ diameter after its volume has doubled 20 times. A further 10 doublings will produce a tumour of $1 \mathrm{~cm}$ diameter. Geddes described how doubling times had been calculated for many lung cancers from serial chest radiographs. Most observations show the doubling time of individual tumours to be constant. Whenever doubling times have been shown to change they tend to have become longer towards the end of the tumour's life: in other words the tumour growth rate slows as the tumour gets larger. His review of published series showed that $80-90 \%$ of tumours grow exponentially. Geddes reviewed published reports of the doubling time of 228 primary lung cancers of which $48 \%$ were squamous cell carcinomas, $26 \%$ adenocarcinomas, $19 \%$ undifferentiated, and $7 \%$ miscellaneous. The mean number of years from malignant change to earliest diagnosis $(1 \mathrm{~cm}$ tumour) was about 8.4 years with the usual mean diagnosis time of $9 \cdot 8$ years. Squamous cell carcinoma takes about $7 \cdot 2$ years to reach $1 \mathrm{~cm}$ size with death if untreated at 9.6 years. Adenocarcinoma takes about 13.2 years to reach $1 \mathrm{~cm}$ size with death at 17.6 years if untreated. Adenocarcinomas on this basis, he predicted, would have an approximate five year survival of $15 \%$, squamous cell carcinomas a five year survival of about $6.5 \%$, and all lung cancers about $8 \%$.

In a series of 35 patients $^{89}$ for whom data were available on tumour size and doubling rate and who were all considered to be operable, the predicted survival rates correlated closely with actual survival rates. 
able 1 Regular attenders of annual works x ray screening sessions from 1955 to February 1964

\begin{tabular}{|c|c|c|c|c|c|c|c|c|c|}
\hline $\begin{array}{l}\text { ge at } \\
\text { agnosis }\end{array}$ & $\begin{array}{l}\text { Detected } \\
\text { at works } \\
x \text { ray } \\
\text { screening }\end{array}$ & $\begin{array}{l}\text { Five year } \\
\text { survival }\end{array}$ & $\begin{array}{l}10 \text { year } \\
\text { survival }\end{array}$ & $\begin{array}{l}\text { Detected } \\
\text { by means } \\
\text { other than } \\
\text { works } x \text { ray } \\
\text { screening }\end{array}$ & $\begin{array}{l}\text { Five year } \\
\text { survival }\end{array}$ & $\begin{array}{l}10 \text { year } \\
\text { survival }\end{array}$ & $\begin{array}{l}\text { Total No } \\
\text { of cases }\end{array}$ & $\begin{array}{l}\text { Total } \\
\text { five year } \\
\text { survival }\end{array}$ & $\begin{array}{l}\text { Total } \\
10 \text { year } \\
\text { survival }\end{array}$ \\
\hline $\begin{array}{l}5-44 \\
5-54 \\
j-64 \\
5-74 \\
\text { otal }\end{array}$ & $\begin{array}{r}1 \\
8 \\
6 \\
2 \\
17\end{array}$ & $\begin{array}{l}0 \\
1 \\
2 \\
0 \\
3\end{array}$ & $\begin{array}{l}0 \\
1 \\
1 \\
0 \\
2\end{array}$ & $\begin{array}{l}0 \\
4 \\
5 \\
0 \\
9\end{array}$ & $\begin{array}{l}0 \\
0 \\
0 \\
0 \\
0\end{array}$ & $\begin{array}{l}0 \\
0 \\
0 \\
0 \\
0\end{array}$ & $\begin{array}{r}1 \\
12 \\
11 \\
2 \\
26\end{array}$ & $\begin{array}{l}0 \\
1 \\
2 \\
0 \\
3\end{array}$ & $\begin{array}{l}0 \\
1 \\
1 \\
0 \\
2\end{array}$ \\
\hline
\end{tabular}

Second or third primary lung cancers have been described, occurring several years after a successful operation. Geddes concluded from predicted growth rates that these are recurrences of first primary and not second or third primary growths. By the time a tumour is detected, it will have passed about $85 \%$ of its life and the overwhelming majority, if not all tumours, will have spread at this stage and the prognosis will depend to a very large degree on the growth rate of the tumour left behind. The small improvement in survival found in practice may be due to treatment, or to slowing of tumour growth towards the end of its life, or a combination of both.

\section{Study population}

Records were available for 227 male employees and two female employees who were diagnosed as having carcinoma of the lung between 1955 and 1989. Of these 229 cases, survival data were available for 124 cases, all now dead, except for one who has survived for more than 10 years. They constitute the population whose records were analysed. Of the 105 cases excluded from this analysis, 101 are known to be dead but date of diagnosis is not known; thus survival times are not available. Four cases, all diagnosed in the period after 1985, are still alive; these are not included in the tables but do consititute potential five and 10 year survivors. None of these four cases was detected at works radiography.

A "regular attender" at the works $x$ ray programme was defined as an employee who had atten- ded three or more consecutive "works" $x$ ray screenings immediately before the diagnosis of lung cancer. It was considered that this constituted an acceptable level of participation in the screening programme.

\section{Results}

Table 1 shows the number of "regular attenders" by age at diagnosis who were detected at annual $x$ ray screening (1955-1964) and those who survived for five and 10 years or more. It also shows those who attended but were detected by means other than the works $x$ ray screening and their five and 10 year survival rate.

There were 26 cases of lung cancer, of whom 17 $(65 \%)$ were detected at works $x$ ray screening and nine $(35 \%)$ were detected by other means. Three survived for five years or more and two for 10 years or more. Of the nine detected by other means there were no five or 10 year survivors. There was a total of three five year survivors $(11.5 \%)$ compared with an expected value of $9 \%$ based on the Office of Population Censuses and Surveys cancer survival data ${ }^{10}$ adjusted for age. There were two 10 year survivors $(7 \cdot 7 \%)$ out of this total group of 26 compared with the expected value of $5 \cdot 2 \%$ (based on the percentage of five year survivors who continued to 10 year survival). ${ }^{11}$

Table 2 shows the number of "regular attenders" by age at diagnosis who were detected at eightmonthly $x$ ray (February 1964 to July 1989), and the number of five and 10 year survivors. It also shows those who had attended but were detected by other

Table 2 Regular attenders at eight-monthly works x ray screening sessions from February 1964 to July 1989

\begin{tabular}{|c|c|c|c|c|c|c|c|c|c|}
\hline $\begin{array}{l}\text { Age at } \\
\text { liagnosis }\end{array}$ & $\begin{array}{l}\text { Detected } \\
\text { at works } \\
x \text { ray } \\
\text { screening }\end{array}$ & $\begin{array}{l}\text { Five year } \\
\text { survival }\end{array}$ & $\begin{array}{l}10 \text { year } \\
\text { survival }\end{array}$ & $\begin{array}{l}\text { Detected } \\
\text { by means } \\
\text { other than } \\
\text { works } x \text { ray } \\
\text { screening }\end{array}$ & $\begin{array}{l}\text { Five year } \\
\text { survival }\end{array}$ & $\begin{array}{l}10 \text { year } \\
\text { survival }\end{array}$ & $\begin{array}{l}\text { Total No } \\
\text { of cases }\end{array}$ & $\begin{array}{l}\text { Total } \\
\text { five year } \\
\text { survival }\end{array}$ & $\begin{array}{l}\text { Total } \\
10 \text { year } \\
\text { survival }\end{array}$ \\
\hline $\begin{array}{l}35-44 \\
15-54 \\
i 5-64 \\
i 5-74 \\
5-84 \\
\text { Cotal }\end{array}$ & $\begin{array}{r}2 \\
5 \\
13 \\
2 \\
0 \\
22\end{array}$ & $\begin{array}{l}0 \\
1 \\
2 \\
0 \\
0 \\
3\end{array}$ & $\begin{array}{l}\mathbf{0} \\
0 \\
0 \\
0 \\
0 \\
0\end{array}$ & $\begin{array}{r}1 \\
2 \\
9 \\
2 \\
1 \\
15\end{array}$ & $\begin{array}{l}0 \\
1 \\
1 \\
0 \\
0 \\
2\end{array}$ & $\begin{array}{l}0 \\
1 \\
1 \\
0 \\
0 \\
2\end{array}$ & $\begin{array}{r}3 \\
7 \\
22 \\
4 \\
1 \\
37\end{array}$ & $\begin{array}{l}0 \\
2 \\
3 \\
0 \\
0 \\
5\end{array}$ & $\begin{array}{l}0 \\
1 \\
1 \\
0 \\
0 \\
2\end{array}$ \\
\hline
\end{tabular}


Table 3 All regular attenders of works $x$ ray screening sessions and others ${ }^{\star}$ diagnosed between 1955 and 1989

\begin{tabular}{|c|c|c|c|c|c|c|}
\hline & $\begin{array}{l}\text { Detected at } \\
\text { works } x \text { ray } \\
\text { screening }\end{array}$ & $\begin{array}{l}\text { Five year } \\
\text { survival }\end{array}$ & $\begin{array}{l}10 \text { year } \\
\text { survival }\end{array}$ & $\begin{array}{l}\text { Detected } \\
\text { by means } \\
\text { other than } \\
\text { works } x \text { ray } \\
\text { screening }\end{array}$ & $\begin{array}{l}\text { Five year } \\
\text { survival }\end{array}$ & $\begin{array}{l}10 \text { year } \\
\text { survival }\end{array}$ \\
\hline $\begin{array}{l}\text { Regular attenders } \\
\text { Others } \\
\text { Total }\end{array}$ & $\begin{array}{r}39 \\
5 \\
44\end{array}$ & $\begin{array}{l}6 \\
2 \\
8\end{array}$ & $\begin{array}{l}2 \\
1 \\
3\end{array}$ & $\begin{array}{l}24 \\
56 \\
80\end{array}$ & $\begin{array}{l}2 \\
1 \\
3\end{array}$ & $\begin{array}{l}2 \\
1 \\
3\end{array}$ \\
\hline
\end{tabular}

*Others are those who did not meet the criteria for inclusion as regular attenders.

means and the number of five and 10 year survivors.

There were 37 cases of whom 22 were detected at works $x$ ray screening. Three survived for five years or more; there were no 10 year survivors. Of the 15 $(41 \%)$ detected by other means, there were two five year survivors and two 10 year survivors. Of the total 37 cases, five survived for five years or more $(13.5 \%$; expected value $8.3 \%$ ) and two $(5.4 \%)$ survived for 10 years or more (expected value $4 \cdot 8 \%$ ).

The detection rate of lung cancer by works $x$ ray screening in regular attenders had decreased from $65 \%$ (1955-1964) to 59\% (1964-1989) even though the frequency of screening had increased from 12monthly to eight-monthly. At the same time, the five year survival of the later group had improved slightly from $11.5 \%$ (expected $9 \%$ ) to $13.5 \%$ (expected $8 \cdot 3 \%)$.

Table 3 shows all lung cancer cases diagnosed between 1955 and July 1989 with known survival data, both regular works $x$ ray screening attenders and others. Of the regular attenders, 39 cases were detected at works $x$ ray screening and of these six survived for five years or more and two survived for 10 years or more. Twenty four were detected by other means with two five year survivors and two 10 year survivors. The total number of cases was 63 , with eight $(12 \cdot 7 \%)$ ) five year survivors (expected $8.6 \%$ ) and four $(6.4 \%) 10$ year survivors (expected $5 \%$ ).

Of the others, five were detected at works screening and of these two survived for five years or more and one for 10 years or more. Fifty six were detected by other means with one five year survivor and one 10 year survivor. The total number of cases was 61 with three $(4.9 \%)$ ) five year survivors (expected $6.4 \%$ ) and two $(3.3 \%) 10$ year survivors (expected $3.7 \%$ ).

Table 3 also shows that those who did not meet the criteria for inclusion as regular attenders (others) have a five year survival rate which is not only less than the regular attenders but less than the expected value for the general population.

Of the total of 124 cases, there were 11 five year survivors and six 10 year survivors. The five year survival rate for the total population of employees for whom survival data is known was $8.9 \%$ (expected $7 \cdot 5 \%$ ). Ten year survival was $4.8 \%$ with $4.3 \%$ expected.

\section{Discussion and conclusions}

The lung cancer detection rate in the 1964-1969 regular attenders decreased compared with the 19551964 group in spite of an increase in the frequency of $x$ ray screening. The five year survival had, however, improved slightly in the 1964-1989 group. The explanation for this may have been a heightened awareness among employees and their doctors of the risk of lung cancer both from exposure to chromates and cigarette smoking, with a greater readiness to seek advice between screening and an increased awareness of the shortcomings of $x$ ray screening as a means of detecting lung cancer at an early stage.

The others had, as expected, a lower five year survival rate than the regular attenders and also a five year survival rate less than expected for the general population. It is likely that this group contained a higher proportion of people who were disinclined to seek advice early on health problems and were not prepared to go through the trauma of seeking out a life-threatening condition every year or every eight months.

No survival data existed for 101 lung cancer cases but their exclusion is not likely to have led to a bias towards a lower survival rate in the study population. Subject to certain conditions, chromates workers and ex-chromates workers were eligible for a special sick pay scheme, which is more likely than not to have increased the number of five and 10 year survivors about whom information was available.

The findings of this review are in line with what would be expected from previous studies and predicted from our.knowledge of tumour growth ratesnamely, no significant improvement in the five year survival of the total population under review (observed $8.9 \%$, expected $7.5 \%$ ) but a greater increase in the five year survival of regular attenders at works $x$ ray screening (observed $12 \cdot 7 \%$, expected $8 \cdot 6 \%$ ). This is likely to be due to earlier detection in the natural history of the disease. It does not mean that people thus detected are cured or live longer than they would have without screening or even have a better quality of life. This increase in survival is less than that found in large scale screening studies, which showed no improvement in mortality from lung cancer. 


\begin{tabular}{|c|c|c|c|c|c|c|}
\hline \multirow[b]{2}{*}{ Total No of cases } & \multicolumn{3}{|c|}{ Total five year survival } & \multicolumn{3}{|c|}{ Total 10 year survival } \\
\hline & No & Obs rate & Exp rate & No & Obs rate & Exp rate \\
\hline $\begin{array}{r}63 \\
61 \\
124\end{array}$ & $\begin{array}{r}8 \\
3 \\
11\end{array}$ & $\begin{array}{r}12 \cdot 7 \% \\
4.9 \% \\
8.9 \%\end{array}$ & $\begin{array}{l}8.6 \% \\
6.4 \% \\
7.5 \%\end{array}$ & $\begin{array}{l}4 \\
2 \\
6\end{array}$ & $\begin{array}{l}6 \cdot 4 \% \\
3 \cdot 3 \% \\
4 \cdot 8 \%\end{array}$ & $\begin{array}{l}5.0 \% \\
3.7 \% \\
4.3 \%\end{array}$ \\
\hline
\end{tabular}

This review shows that $x$ ray screening has not had a significant impact on the five or 10 year survival rates of employees with carcinoma of the lung for whom data were available. It confirms the findings of other workers that lung cancer is not at present a disease which meets the criteria that justify screening to detect it early.

Carcinoma of the lung is known to be a largely preventable disease with $90 \%$ of cases attributable to cigarette smoking. ${ }^{12}$ Once contracted, it is a form of cancer that is highly malignant and virtually incurable.

It was recommended that the programme of eightmonthly $x$ ray screening should be discontinued and that the continuing programme to reduce exposure to hexavalent chromium should be coupled with restrictions on smoking in the workplace and a campaign aimed at encouraging employees to give up smoking.

1 Machle W, Gregorius F. Carcinoma of the respiratory system in the United States chromate-producing industry. Public Health Rep 1948;63:1114-27.
2 Baetjer AM. Pulmonary carcinoma in chromate workers 2. Incidence on basis of hospital records. Archives of Industrial Hygiene and Occupational Medicine 1950;2:505-16.

3 Bidstrup PL. Carcinoma of lung in chromate workers. Br J Ind Med 1951;8:302-5.

4 Bidstrup PL, Case RAM. Carcinoma of the lung in workmen in the bichromates-producing industry in Great Britain. Br J Ind Med 1956;13:260-4.

5 Brett GZ. Earlier diagnosis and survival in lung cancer. $B M J$ $1969 ; 4: 260-2$.

6 Fontana RS. Lung cancer screening: the Mayo program. JOccup Med 1986;28:746-50.

7 Geddes DM. The natural history of lung cancer: a review based on the rates of tumour growth. Br J Dis Chest 1979;73:1-17.

8 Weiss W, Boucot KR, Cooper DA. Growth rate in the detection and prognosis of bronchogenic carcinoma. Journal of the American Medical Association 1966;198:1246-52.

9 Meyer JA. Growth rate versus prognosis in resected primary bronchogenic cancer. Cancer 1973;31:1468-72.

10 Office of Population Censuses and Surveys. OPCS monitor cancer survival 1976 to 1978 (registrations MB1 84/1). Cancer survival 1977 to 1979 (registrations MB1 85/1). Cancer survival 1978 to 1980 (registrations MB1 86/1). Cancer survival 1980 to 1981 (registrations MB1 86/2). London: HMSO.

11 The Registrar General's statistical review 1958-70. Ten-year survival data for patients registered in 1955. London: HMSO, 1975.

12 Doll R, Peto R. The causes of cancer. Oxford: Oxford University Press, 1981.

Accepted 18 February 1991 